\title{
Movement of satellite-tracked juvenile saker falcons (Falco cherrug) in SW Slovakia
}

\author{
Pohyb satelitne sledovaných juvenilov sokola rároha (Falco cherrug) na JZ Slovensku
}

\author{
Vladimír NEMČEK, Jozef CHAVKO \& Lucia DEUTSCHOVÁ
}

\begin{abstract}
During the period 2008-2011 nine juvenile saker falcon females from SW Slovakia were tracked with satellite telemetry. The movement of four of those females tagged with satellite tracking devices was analysed in 2011 (two juveniles for 6 months, one for 5 months and one for 3 months). The analysis of the collision risk with wind turbines also used telemetry data from previous years (2008-2009) - five birds tracked from abandoning their nest to abandoning their post-fledging areas (i.e. 45, 48, 37, 113 and 134 days). The juveniles visited 13 different countries during their post-fledging dispersal and migration. Maximum distance from the nest varied between 153 and $2094 \mathrm{~km}$. For two birds the cause of death was recorded: one female was electrocuted and other female was probably also electrocuted. We also evaluated two factors of potential wind turbine threat: a) the distance of GPS locations from the nearest wind turbines in the vicinity of post-fledging areas, $b$ ) numbers of wind turbines in post-fledging areas. Assessment of the collision risk with wind turbines showed low risk for the tracked individuals. Two of four tracked birds were at medium risk $(2-5 \mathrm{~km})$ from wind turbines. The highest risk for the young falcons comes from wind turbines in neighbouring countries, where they are constructed near borders.
\end{abstract}

\begin{abstract}
Abstrakt: Počas rokov 2008-2011 bolo sledovaných satelitnou telemetriou 9 juvenilných samíc sokola rároha s pomocou satelitnej telemetrie. Pohyb bol analyzovaný pre štyri samice z nich, označené satelitnými vysielačkami v roku 2011 (dva juvenily sa sledovali počas 6 mesiacov, jeden počas 5 mesiacov a jeden počas 3 mesiacov). V analýze rizika kolízie s veternými turbínami boli tiež použité údaje zo satelitnej telemetrie z predchádzajúcich rokov (2008-2009) - pät' jedincov sledovaných od opustenia hniezda po opustenie oblasti obývanej po vyletení $(45,48,37,113$ a 134 dní). Juvenily navštívili 13 rozličných krajín počas disperzie po opustení hniezdiska. Maximálna vzdialenost' od hniezda kolísala medzi 153 až $2094 \mathrm{~km}$. Pri dvoch vtákoch bola zaznamenaná príčina smrti - jedna samica bola usmrtená elektrickým prúdom a d’alšia samica bola tiež pravdepodobne usmrtená elektrickým prúdom. Tiež sme hodnotili dva faktory potenciálneho ohrozenia veternými turbínami - a) vzdialenost' GPS lokácií od najbližších veterných turbín v okolí oblasti obývanej po vyletení, b) počet veterných turbín nachádzajúcich sa v oblasti obývanej po vyletení. Zhodnotenie rizika kolízie s veternými turbínami ukázalo nízke riziko pre sledované jedince. Dva zo štyroch sledovaných vtáky boli v strednom ohrození veternými turbínami. Najvyššie riziko pre mladé sokoly predstavujú veterné turbíny v susedných krajinách - postavené blízko hraníc.
\end{abstract}

Key words: wind farms, collision risk, migration, satellite telemetry

Vladimír Nemček, Jozef Chavko, Lucia Deutschová, Raptor Protection of Slovakia, Kuklovská 5, 84104 Bratislava, Slovakia. E-mail:nemcek@dravce.sk, chavko@dravce.sk,deutschova@dravce.sk.

Acknowledgement: We would like to thank Boris Maderič, Marcel Uhrin, Michal Noga, Mátyás Prommer, David Horal, Martin Dobrý and local ornithologists from Bulgaria and Germany, who helped us in the field and provided information for us. This article uses data obtained in these LIFE projects: LIFE09 NAT/HU/000384 Conservation of Falco cherrug in NE Bulgaria, Hungary, Romania and Slovakia, and LIFE06 NAT/H/000096 Conservation of saker (Falco cherrug) in the Carpathian Basin.

\section{Introduction}

The saker falcon (Falco cherrug) is a palaearctic bird species. It breeds from Mongolia westwards to Iran, central Turkey, southern Russia and Central Europe and is considered to be a partial migrant (Prommer et al. 2012). It has been observed in both Central Europe and Asia that adult birds are sedentary or their movements are dependent on the prey availability, while juveniles show long-distance migratory behaviour. These patterns were revealed by ringed bird recoveries or as the results of the first radio and/or satellite telemetry studies (e.g. Eastham 1998, Potapov et al. 2000, 2002, Chavko 2002, Karyakin et al. 2005, Prommer et al. 2012). In Slovakia and in Moravia (the Czech Republic), analysis of ringing data has shown very limited, but similar movement patterns (Schröpfer 2008, Slobodník 2008, Slobodník et 
al. 2009, Slobodník \& Slobodník 2010, 2012). Sakers from this region have been found in Hungary, Austria, Croatia and Italy. The birds ringed in Hungary and Austria were later observed in Slovakia. Young sakers were found mainly further southwards, in Italy, France, Hungary, and also in North Africa in Libya.

Satellite tracking also helps to answer many ecological questions. A relatively new issue in raptor conservation is the level of threat from "wind farms". In Europe there is strong pressure for using "green energy", especially wind energy. But wind turbines increase mortality of resident and migrating birds and destruction of foraging and nesting habitats (Fielding et al. 2006, Jana \& Pogacnik 2008, Smallwood \& Thelander 2008, Schaub 2012) For the population in Slovakia, the real threat is unknown. Data from satellite telemetry were processed and analyzed in GIS to determine if young sakers in the natal area are at risk of collision with wind turbines.

\section{Material and methods}

To study juvenile saker dispersal and migration we used the method of satellite tracking (Meyburg \& Fuller 2007). Satellite-linked solar-charged Platform Transmitter Terminals (PTT) with embedded Global Positioning System (GPS) units weighing $22 \mathrm{~g}$ (Microwave Telemetry, Inc.; PTT-100 Solar Argos/GPS) were mounted on the birds as a backpack using a special teflon ribbon for harnessing. The weight of transmitters respected the $5 \%$ rule accepted for such research (Aldridge \& Brigham 1988, Kenward 2001). The PTTs were attached only to females, because they are larger than the males and they have no difficulty carrying these devices. We used the data from the embedded GPS units only for further evaluation, because of their greater accuracy (better than $100 \mathrm{~m}$ ). The transmitters were set to locate the birds six times a day between April $1^{\text {st }}$ and September $30^{\text {th }}$ and three times a day during the rest of the year. Location fixes were recorded during the day within the period from $6.00 \mathrm{am}$ to $6.00 \mathrm{pm}$ or from $7.00 \mathrm{am}$ to $7.00 \mathrm{pm}$ in Greenwich Mean Time (GMT) respectively. Data were downloaded in PRV/DS format and MTI GPS Data Parser software (Microwawe Telemetry, Inc.) was used to transform the data into text files and Google Earth files (Google Inc. 2010) with coordinates and times of the fixes recorded. Coordinates in WGS84 format were used in the analysis. Four individuals were tagged by PTTs in June 2011. Two females were siblings from a nest located in the Záhorská nížina Lowland. The other two females came from other nests located in the Záhorská nížina Lowland and the Podunajská nížina Lowland respectively. To analyse the saker falcons' movement we used Quantum GIS 2.2 (2014) to calculate travel distance and distance from the natal area. Maps of movements were also produced in this program. We used spatial reference system EPSG:3035 (ETRS89 / ETRS-LAEA) for Europe for calculation.

\section{Thre a t f r o m w in d $\mathrm{t}$ u r b i n e s}

To assess the threat from wind farms we used data from satellite tracking of young saker falcons. Data were evaluated for the period during their stay in the postfledging areas. We characterized post-fledging areas as areas where the distance between nearest night perches did not exceed 10 kilometers. We considered each night perch site as the position received from transmitters at 18:00 or 19:00 GMT. In cases where such data were missing, the position from the time closest to 18:00 GMT was considered as the night perch site. Threats from wind farms were evaluated for 9 individuals: four individuals were tagged with PTTs in 2011 (their movement was also analyzed and described; see details in previous section) and the other five individuals were tagged with PTTs in 2008 and 2009. These five individuals came from nests located in the Záhorská nížina Lowland (1 female), Malé Karpaty Mts (1 female) and in the Podunajská nížina Lowland (3 females). The movement data of these individuals were analyzed in a previous study (Prommer et al. 2012), so we do not described their movements in this study. We analyzed two factors: a) the distance of GPS locations from the nearest wind turbines in the vicinity of post-fledging areas, and b) numbers of wind turbines in the postfledging areas (represented by minimum convex polygons (MCP) and fixed kernel polygons (95\% FKP)). The location distances from wind turbines were separated to three categories: high risk $(0-2 \mathrm{~km})$, medium risk $(2-5 \mathrm{~km})$ and low risk $(5-10 \mathrm{~km})$. Based on the telemetry data the average distance between following locations was determined $(1.4 \mathrm{~km})$, which helped to predict the average potential occurrence of each bird around the previous GPS location. Telemetry data did not contain the birds' altitude, so the threat to young sakers may be lower in the real situation. The wind turbines were located using Google Earth and maps of wind turbines (http://www.thewindpower.net). To analyse the threat to sakers based on the distance and numbers of wind turbines from GPS locations, we used the Quantum GIS 1.8.0 programme. 


\section{Results and discussion}

Move me $\mathrm{n} \mathrm{t}$

The length of individual movements varied among individuals due to various recorded times and movement character (Appendix 1).

The saker with PTT number 66450 spent time in the vicinity of the nest (max. $8 \mathrm{~km}$ from the nest) until leaving the natal area (Fig. 1). It left that area at the beginning of August and crossed the Slovakian border in the north-eastern part. For three days the saker flew over Ukraine and continued to Russia. There the first temporary settlement area was recorded, $140 \mathrm{~km}$ northeast from Moscow. Saker 66450 remained in the temporary settlement area from August $9^{\text {th }}$ to September $7^{\text {th }}$. Its movement with a short pause continued to Georgia, but when the bird flew over the Caucasus Mountains it then flew back to Russia (60 km from the border with Georgia). This was the second TSA where it remained from September $18^{\text {th }}$ to November $5^{\text {th }}$ (the last location).

The individual with PTT number 66491 remained in the natal area until July $9^{\text {th }}$ (Fig. 2). From this date it flew over Austria, the Czech Republic and south of Poland. Then it crossed the north Slovakian border and flew over Slovakia and part of Hungary to Austria, taking short rest breaks near Neusiedl am See and between Linz and Salzburg. From Austria its movement continued to Germany where a TSA was located near the town of Erfurt. Saker 66491 remained in this area from July $19^{\text {th }}$ to September $1^{\text {st }}$. During the stay in the TSA it carried out an exploratory flight to the vicinity of the town of Uelzen (80 km from Wolfsburg). From the TSA it flew south-west and stopped in the vicinity of Mainz. There it remained from September $3^{\text {rd }}$ to September $12^{\text {th }}$. The next TSA was located in France, near Toulouse (from September $22^{\text {nd }}$ to November $5^{\text {th }}$, the last recorded location).

The individual 66492 (Fig. 3) remained in the vicinity of the nest until July $14^{\text {th }}$ (max. $7 \mathrm{~km}$ from the nest). After this date it flew to Austria, near Durnkrut (13 km from the nest). It stayed in this area until July $27^{\text {th }}$. Then the saker moved to the Czech Republic, to a TSA near Olomouc. There it carried out exploratory flights up to $78 \mathrm{~km}$ from the TSA. The last location came from the TSA, where the saker was found dead below an electricity pylon in August $14^{\text {th }}$.

The individual 66493 remained in the natal area until July $13^{\text {th }}$ (Fig. 4). The movement during this period was restricted to $4 \mathrm{~km}$ from the nest. After this date it flew over the Czech Republic, the north part of
Slovakia and the border area with Poland, where it changed flight direction to the south and flew back over Slovakia to an area in south-east Hungary, $20 \mathrm{~km}$ from Debrecen. Here it remained from July $18^{\text {th }}$ to August $2^{\text {nd }}$. The next part of its migration was a flight over Romania to a temporary settlement area $30 \mathrm{~km}$ from Constanta on the Black Sea coast. The TSA was occupied from August $4^{\text {th }}$ to October $22^{\text {nd }}$. From this TSA it moved to another TSA in the vicinity of Stara Zagora in Bulgaria. Here the saker 66493 remained from October $25^{\text {th }}$ to March $20^{\text {th }}(2012)$. It was found in this area in late December by members of the Green Balkans Federation, in a field with its legs and wings entangled in a nylon string. From March it moved to the Czech Republic (the vicinity of Prague) where it carried out exploratory flights, $\max .400 \mathrm{~km}$ from the TSA. It remained in this TSA from March $28^{\text {th }}$ to May $1^{\text {st }}$. From May it resumed movement over Poland, Lithuania, Belarus, Ukraine and Moldova, and finished in the southern part of Ukraine $(30 \mathrm{~km}$ north of the Crimean peninsula). Saker number 66493 remained in this TSA from June $1^{\text {st }}$ to September $26^{\text {th }}$. The last part of its movement continued over the coast of Ukraine, the southern part of Moldova and Romania to Bulgaria, to a TSA in the vicinity of Stara Zagora (October $5^{\text {th }}$-October $25^{\text {th }}$ ). Remains of the saker and PTTs were later found in the vicinity of power lines.

Telemetry data showed great variability in these saker falcon movements. They were similar to the direction of movements found in a previous study (Prommer et al. 2012). Main TSAs were located in Central and Eastern Europe. Bird number 66493 was rescued in Bulgaria by members of the Green Balkans Federation. After rehabilitation it was launched near Stara Zagora (central Bulgaria). The track of this bird was interesting, because it visited the TSA near Stara Zagora again one year later. Two birds probably died after collision with power lines. Electricity lines and pylons still represent the greatest danger for saker falcons. Conservation strategy should be aimed at pylon adaptation, illegal shooting and habitat degradation in important TSAs.

Threat from wind t u r bi ne s In the western part of Slovakia there is only one place with wind turbines, in the Malé Karpaty Mts near the village of Cerová. Another potential threat for saker falcons in Slovakia is presented by wind farms in the border area between Austria and Hungary. No locations of falcons were recorded within the distance of high risk 


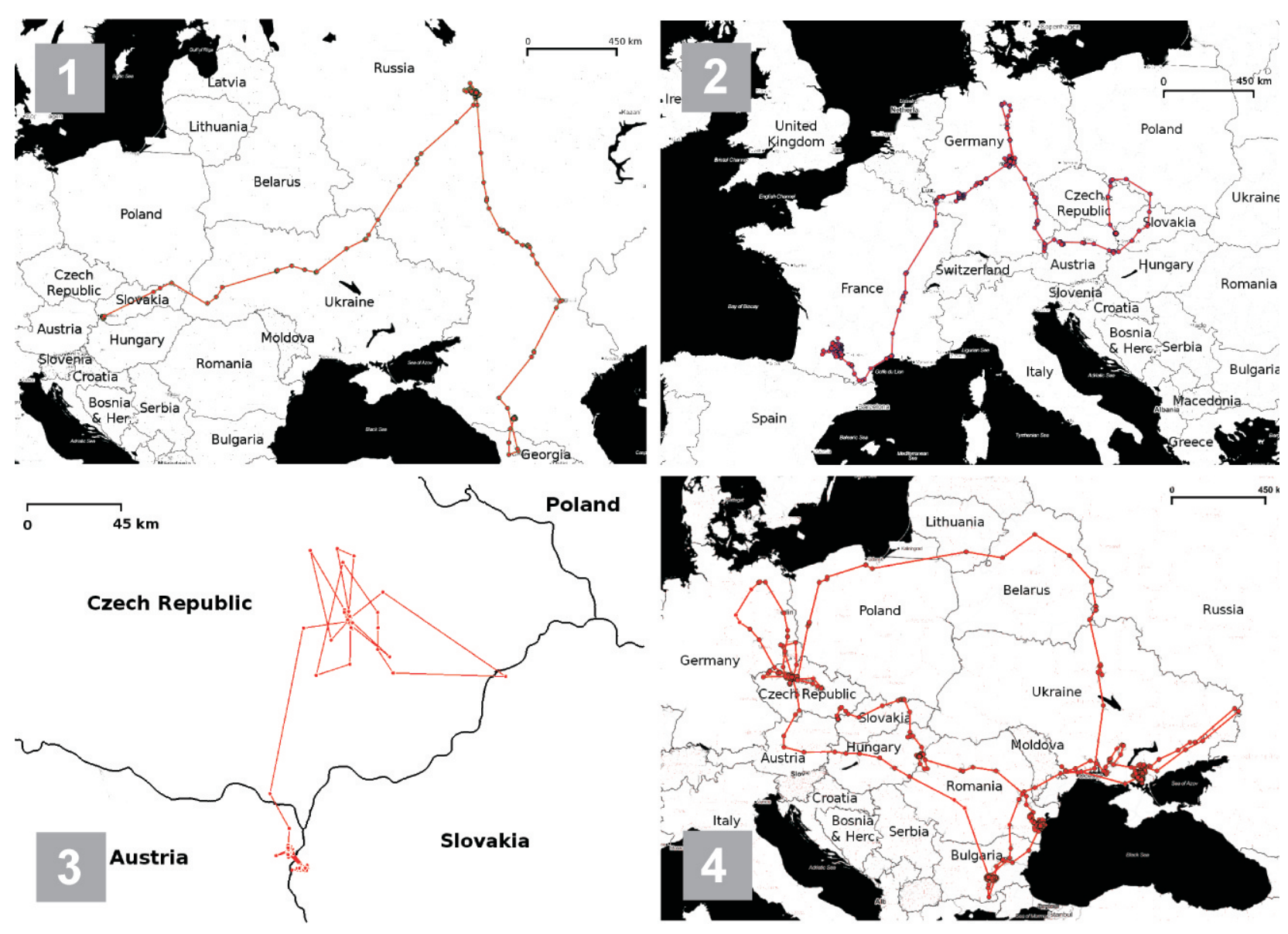

Figs. 1-4. Track of saker number 66450 (1), 66491 (2), 66492 (3) and number 66493 (4)

Obr. 1-4. Trasa sokola rároha číslo 66450 (1), 66491 (2), 66492 (3) a číslo 66493 (4)

from wind turbines (Tab. 1). Two birds were recorded in the distance of medium risk from wind turbines (Fig. 5 and 6). The potential collision risk was identified as medium for bird number 66492 (77 locations up to five kilometers from turbines, $25.58 \%$ of all locations). Other bird locations were at greater distances from turbines. In the post-fledging areas represented by minimum convex polygons (MCPs) 62 wind turbines were identified (Tab. 1). The highest number of turbines in the MCP was encountered during exploratory flights, when sakers flew long distances exploring the landscape. In $95 \%$ of fixed kernel polygons (FKPs) there were no turbines. The exploratory flights represent a major collision risk for young, inexperienced sakers in the post-fledging areas, because in the vicinity of the nests (in Slovakia) there is low potential for collision with wind turbines.
Telemetry data showed relatively low probability of collision risk for monitored young sakers. Potential threat exists in the border zone in western Slovakia, where there is a high concentration of wind farms. The next step in decreasing the threat of collision is consideration of the construction of new wind farms, based on telemetry data for endangered species. Especially in the border zone it is necessary to receive data for endangered species from all bordering countries. Numbers of saker pairs hunt in the border zones. For obtaining more accurate data to assess collision risk it is necessary to use telemetry with shorter track intervals and altitude sensors, and to identify the most important habitats in the core areas for juveniles and adults. Wind turbines represent a danger especially for large birds with poor maneuverability (Brown et al. 1992). Turbines have an impact on raptors in three ways: possible loss of for- 
Slovak Raptor Journal 2014, 8(2): 97-103. DOI: 10.2478/srj-2014-0011.

(C) Raptor Protection of Slovakia (RPS)

Tab. 1. Number of birds' locations at various distances from turbines and number of wind turbines in post-fledging areas

Tab. 1. Počet polôh jedincov v rôznej vzdialenosti od veterných turbín a počet veterných turbín v oblasti obývanej po vyletení

\begin{tabular}{|c|c|c|c|c|c|c|c|c|}
\hline \multirow{2}{*}{$\begin{array}{l}\text { ind. No. / } \\
\text { jedinec č. }\end{array}$} & $\begin{array}{l}\text { high } \\
(0-2 \mathrm{~km}) /\end{array}$ & \multicolumn{2}{|c|}{ risk / riziko } & \multicolumn{3}{|c|}{$\begin{array}{l}\text { No. of locations from wind } \\
\text { turbines }(\%) \text { at the distance / }\end{array}$} & \multirow[t]{2}{*}{$\begin{array}{l}\text { No. of locations } \\
\text { at post-fledg. areas / } \\
\text { Počet polôh jedinca } \\
\text { v obl. po vyletení }\end{array}$} & \multirow[t]{2}{*}{$\begin{array}{l}\text { No. of turbines } \\
\text { at post-fledg. areas / } \\
\mathrm{N} \text { turbín } \\
\mathrm{v} \text { obl. po vyletení }\end{array}$} \\
\hline & vysoké & stredné & nízke & $0-2 \mathrm{~km}$ & $2-5 \mathrm{~km}$ & $5-10 \mathrm{~km}$ & & \\
\hline 53589 & 0 & 0 & 0 & 0 & 0 & 0 & 215 & 0 \\
\hline 53303 & 0 & 0 & 8 & 0 & 0 & 0.32 & 241 & 0 \\
\hline 54077 & 0 & 0 & 0 & 0 & 0 & 0 & 185 & 0 \\
\hline 66450 & 0 & 0 & 0 & 0 & 0 & 0 & 309 & 0 \\
\hline 66491 & 0 & 0 & 3 & 0 & 0 & 1.51 & 199 & 0 \\
\hline 66492 & 0 & 77 & 12 & 0 & 25.58 & 3.99 & 301 & 10 \\
\hline 66493 & 0 & 0 & 0 & 0 & 0 & 0 & 205 & 0 \\
\hline 93180 & 0 & 1 & 2 & 0 & 0.27 & 0.54 & 369 & 5 \\
\hline 93190 & 0 & 0 & 2 & 0 & 0 & 0.4 & 512 & 47 \\
\hline
\end{tabular}

aging or nesting habitats, breeding disturbance, and collision risk (Seaton \& Barea 2013). Loss of foraging habitats may be a problem in areas with many wind farms. Due to the low incidence of turbines in Slovakia, this threat is higher for pairs nesting in the border zones near Austria and Hungary. Saker falcons are universal predators, but their primary historical prey in Slovakia was the souslik, which requires pasture land (Obuch \& Chavko 1997). This habitat may be endangered on a local level by the construction of wind turbines on pasture land. In the current period, the major risk for the Slovakian saker population lies in the construction of wind farms in neighbouring countries (Austria and Hungary).

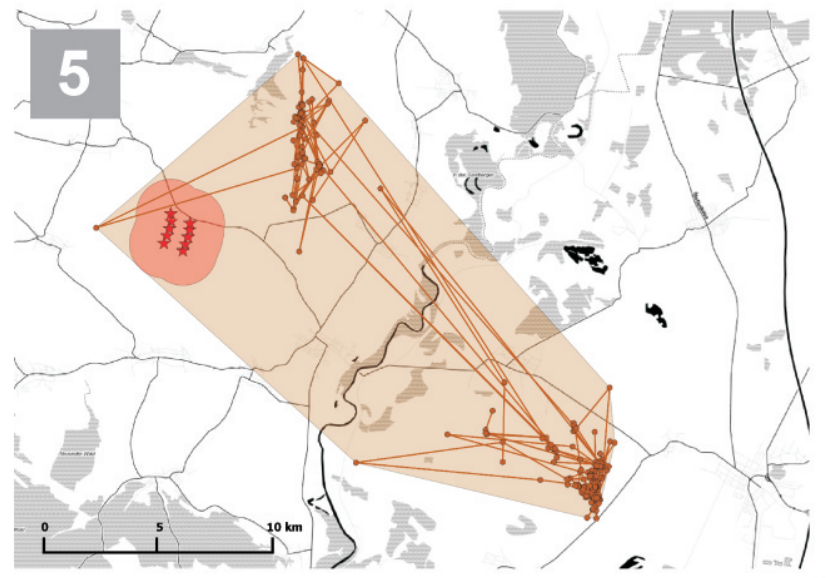

\section{References}

Aldridge HDJN \& Brigham RM 1988: Load carrying and manoeuvrability in insectivorous bats: a test of $5 \%$ "rule" of radio-telemetry. Journal of Mammalogy 69: 379-382. DOI: 10.2307/1381393

Brown MJ, Linton E \& Rees EC 1992: Causes of mortality among wild swans in Britain. Wildfowl 43: $70-79$.

Chavko J 2002: Sokol rároh (Falco cherrug) [The saker falcon (Falco cherrug)], 214-216. In: Danko S̆, Darolová A \& Krištín A (eds), Rozšírenie vtákov na Slovensku [Birds distribution in Slovakia]. Veda. Bratislava, 688. [In Slovak with English summary]

Eastham C 1998: Satellite tagging sakers in the Russian Altai. Falco 12: 10-12.

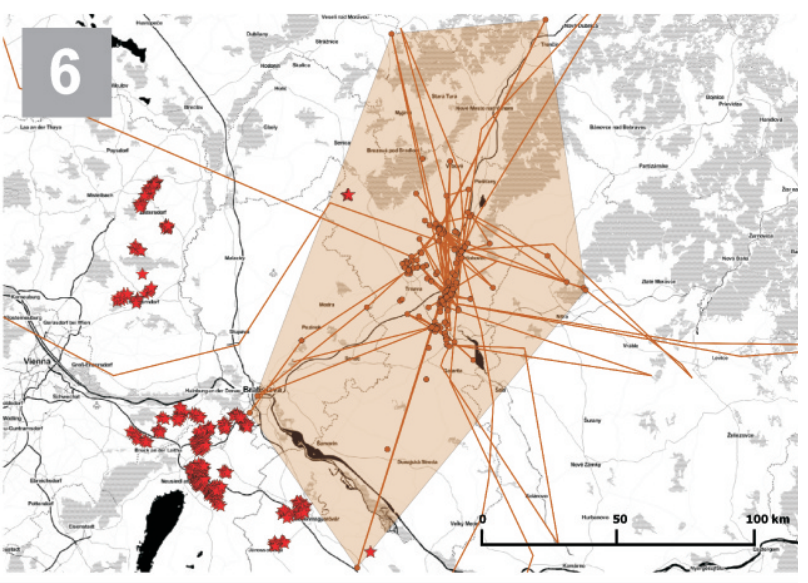

Figs. 5-6. Movement of saker falcon number 66492 (5) and 93180 (6) in the post-fledging area. Track of movement is shown by the line, points represents GPS locations and MCP represents post-fledging area. Wind turbines are shown by star symbols

Obr. 5-6. Pohyb sokola rároha číslo 66492 (5) a 93180 (6) v oblasti obývanej po vyletení. Trasa pohybu je zobrazená čiarou, body predstavujú GPS polohy a MCP predstavuje oblast' obývanú po vyletení. Veterné turbíny sú zobrazené symbolmi hviezd 
Fielding AH, Whitfield DP \& McLeod DRA 2006: Spatial association as an indicator of the potential for future interactions between wind energy developments and golden eagles Aquila chrysaetos in Scotland. Biological Conservation 131: 359-369. DOI: 10.1016/j.biocon.2006.02.011

Google Inc 2010: Google Earth (Version 5.1.3533.1731) [Software]. Available from http://en.softonic.com/s/google+earth +5.1 .3533 .1731$

Jana S \& Pogacnik M 2008: The impacts of wind farms on animal species. Acta Veterinaria-Beograd 58: 615-632. DOI:10.2298/Avb0806615s

Karyakin IV, Nikolenko EG, Potapov E R \& Fox N 2005: Preliminary results of the project on migration studies of the saker falcon in Russia. Raptors Conservation 2: 56-59.

Kenward R 2001: A manual for wildlife radio tagging. Academic Press. London, 311.

Meyburg BU \& Fuller MR 2007: Satellite tracking. Pp.: 242-248. In: Bird DM \& Bildstein KL (eds), Raptor Research and Management Techniques. Hancock House Publishers. Surrey, 464.

Obuch J \& Chavko J 1997: The diet of the saker falcon (Falco cherrug) in SW Slovakia. Buteo 9: 77-84

Potapov E, Fox N, Shagdarsuren O, Sumya D \& Gombobaatar S 2000: Home ranges of saker falcons in Mongolia. Falco 15: 10-11.

Potapov E, Fox NC, Sumya D \& Gombobaatar S 2002: Migration studies of the saker falcon. Falco 19: 3-4.

Prommer M, Bagyura J, Chavko J \& Uhrin M 2012: Migratory movements of Central and Eastern European saker falcons (Falco cherrug) from juvenile dispersal to adulthood. Aquila 119: 111-134.

Quantum GIS Development Team 2014: Quantum GIS Geographic Information System. Open Source
Geospatial Foundation Project. Retrieved September 1, 2014, from http://qgis.orgt

Schröpfer L 2008: Raroh velký. Falco cherrug. Sokol rároh. Saker falcon, 291-292. In: Cepák J, Klvaňa P, Škopek J, Schröpfer L, Jelínek M, Hořák D, Formánek J \& Zárybnický J (eds), Atlas migrace ptáků České a Slovenské republiky. Czech and Slovak bird migration atlas. Aventinum. Praha, 608.

Seaton R \& Barea LP 2013: The New Zealand falcon and wind farms: a risk assessment framework. New Zealand Journal of Zoology 40: 16-27. DOI: $10.1080 / 03014223.2012 .754361$

Slobodník V 2008: Summary on raptors and owls ringing in Slovakia in the period 2005-2006. Slovak Raptor Journal 2: 113-117. DOI: 10.2478/v10262012-0025-3

Slobodník V \& Slobodník R 2010: The summary on raptors and owls ringing in Slovakia in 2009. Slovak Raptor Journal 4: 109-113. DOI: 10.2478/v10262012-0053-z

Slobodník V \& Slobodník R 2012: Summary of raptor and owl ringing in Slovakia in 2011. Slovak Raptor Journal 6: 41-44. DOI: 10.2478/v10262-012-0063-x

Slobodník V, Slobodník R \& Dravecký M 2009: Summary on raptors and owls ringing in Slovakia in 2007 and 2008. Slovak Raptor Journal 3: 63-72. DOI: $10.2478 / \mathrm{v} 10262-012-0035-1$

Schaub M 2012: Spatial distribution of wind turbines is crucial for the survival of red kite populations. Biological Conservation 155: 111-118. DOI:10.1016/j.biocon.2012.06.021

Smallwood KS \& Thelander C 2008: Bird mortality in the Altamont Pass Wind Resource Area, California. Journal of Wildlife Management 72: 215-223. DOI: 10.2193/2007-032 
Slovak Raptor Journal 2014, 8(2): 97-103. DOI: 10.2478/srj-2014-0011.

(C) Raptor Protection of Slovakia (RPS)

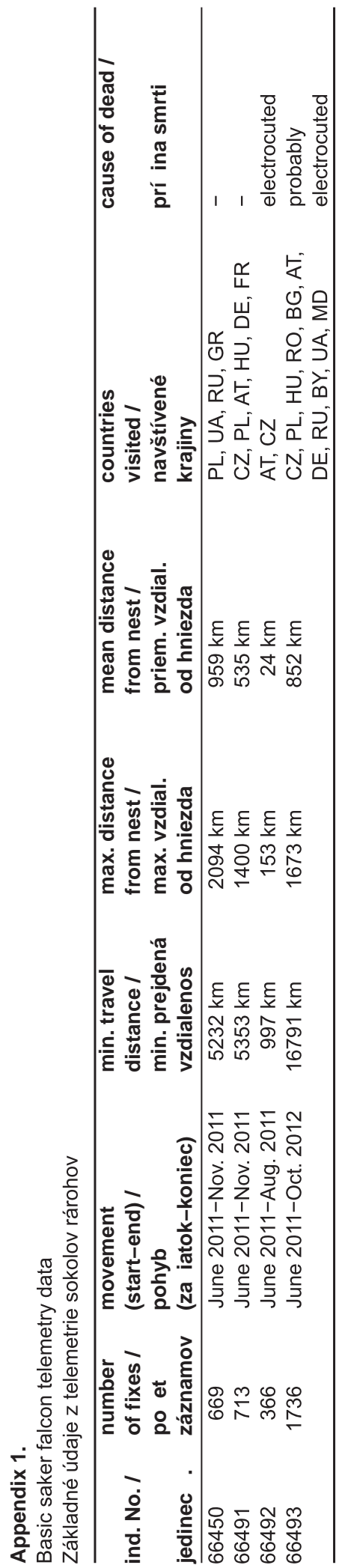

